\title{
The Health Belief Model and Prediction of Breast Self-examination Practices in Female Mexican College Students
}

\author{
Dehisy Marisol Juárez-García*, Arnoldo Téllez
}

Autonomous University of Nuevo Leon, Mexico

${ }^{\star}$ Corresponding author. E-mail: dehisy_jg@yahoo.com.mx

Background: Cancer incidence and mortality in young Latin American women has increased over the last few decades. In Mexico, breast self-examination (BSE) is recommended from 20 years of age to create awareness of breast cancer and detect body changes. The health belief model (HBM) allows us to identify young women's beliefs about cancer and BSE, which could help us to design more appropriate strategies to promote BSE in the fight against breast cancer.

Objective: To assess the knowledge, practice, and beliefs about cancer and BSE in female college students; examine the differences between those who practice BSE and those who do not; and determine the most influential variable for performing BSE.

Design: A descriptive cross-sectional design was used; the Health Belief Model scale for BSE was applied to 949 female college students from a public university.

Results: This Major health study showed that suffering benign breast disease and having a family history of breast cancer was associated with BSE performance; it also found that the dimensions of the health beliefs model differed depending upon barriers, benefits, self-efficacy and health motivation were different between women who perform an BSE in. The predicting variables for BSE practice were self-efficacy, the barriers perceived, benign breast disease, and the major subject of study.

Conclusion: Reports of BSE practice in female students from Latin American countries are similar; however, the predictive variables differ from those found in the general population. Perceived barriers and self-efficacy are factors capable of modification, and must be addressed by BSE promotion strategies aimed at female college students.
Key words: breast selfexamination (BSE); breast cancer; cancer education; health belief model (HBM); college student health 


\section{Introduction}

In Mexico, breast cancer is one of the main causes of hospital cancer morbidity in women aged 20 years and older (30.9\%), and its mortality is higher than the mortality rates for all types of male cancer combined. Breast cancer mortality rates showed an upward trend from 2011 to 2016, with the highest rate in 2016, totalling 16 deaths per 100,000 women aged 20 years and older (National Institute of Statistics and Geography [INEGI], 2017; INEGI, 2018).

Breast cancer morbidity and mortality affect the quality of life of Mexican women. One of the main reasons for the high breast cancer mortality rates is that most cancers are being detected in the late stages, which explains the importance of increasing and strengthening the implementation of strategies focused on early detection (Mexican Health Secretary, 2013).

According to the Official Mexican Standard (NOM), the promotion of breast cancer detection must include breast self-examination (BSE), the clinical breast exam, and the mammogram (MMG). BSE is recommended from the age of 20 years, and its objective is to create awareness in women about the risk of breast cancer, so that they have better knowledge of their own bodies and are able to identify abnormal changes, and seek adequate medical care (Mexican Health Secretary, 2011).

In Mexico, an increased prevalence of breast cancer in young women under the age of 40 has been observed, comprising $10 \%$ of cases, with the youngest recorded case at 23 years of age. Most of the cases detected were in stage III (De la Vara-Salazar, Suárez-López, Ángeles-Llerenas, Torres-Mejía, \& Lazcano-Ponce, 2011; Martínez-Cruz, Juárez-Ramiro, Pichardo-Cuevas, \& Martín-Ordoñez, 2010). From 2000 to 2009 , the breast cancer mortality rate increased by $13.7 \%$ in women aged 23 to 29. Therefore, the Mexican health system faces the challenge of increasing the early detection of breast cancer in younger asymptomatic women (RoblesCastillo, Ruvalcaba-Limón, Maffuz-Aziz, \& Rodríguez-Cuevas, 2011).

Socio-demographic and psychological factors determine whether a woman performs a BSE or not. Most of the studies conducted in Mexico have focused on socio-demographic factors associated with BSE, such as information available to the general population, general practitioner training, first contact with gynecologists, and fears of the partner and the family (Nigenda, Caballero, \& GonzálezRobledo, 2009). Women from lower socioeconomic strata, with lower educational attainment, and without access to health services, engage in significantly lower detection practices than the national average (Agudelo-Botero, 2013).

However, in addition to healthcare provider training needs, in order to ensure greater MMG coverage and the use of breast cancer early detection (offered at no cost), we must consider the cultural obstacles that prevent women from visiting the doctor and pursuing the required treatment. Some women believe that women with breast cancer are considered less feminine, and are abandoned by their partners (Frenk, 2009).

Few studies have been conducted in Mexico about BSE beliefs and practices in young women. Two studies conducted with adolescents focused on their perception of breast cancer campaigns and early detection. The results showed that more information and breast health services for teenagers are required. These studies also reported some of the obstacles to the early detection of the disease, including 
male chauvinism, Marianism, nosophobia, and limited access to information and health services (Tapia-Curiel, Villaseñor-Farías et al., 2014; Tapia-Curiel, NuñoGutiérrez et al., 2015).

In another study, done with female nursing students in the southern area of Mexico, 59\% had knowledge of BSE. The main reasons they gave for performing the examination were "timely detection and cure"; "for pain, masses, and/or discharge"; "it is beneficial, inexpensive, and simple"; and "to know if one is healthy." The main myths detected among the students were "it is a sin," "the breasts loosen," and "self-examination is a morbid practice" (Tenahua-Quitl et al., 2017).

For this reason, in addition to the socio-demographic factors, it is important to identify the cognitive factors associated with these health theories and models, to better understand such behavior and non-adherence to breast cancer detection strategies (Ahmadian \& Samah, 2013). The Health Belief Model (HBM) has been used to identify the relevant factors needed to ensure a woman performs BSE (Champion, 1984). This model is focused on two aspects of individual perceptions and health behavior: the perception of a threat, and a behavioral assessment. Threat perception includes the woman's view of her susceptibility to the disease and the severity of its consequences. The behavioral assessment includes beliefs about the benefits and efficacy of the recommended behavior and the barriers to its implementation. The model also includes the person's general health motivation - that is, her predisposition to taking care of her own health (Abraham \& Sheeran, 2015).

Studies show that the different dimensions of HBM influence BSE practice differently. Perceived benefits, perceived self-efficacy, and health motivation have a strong association with performing BSE in Iranian women (Hajian-Tilaki \& Sahar Auladi, 2014); female students who had greater health motivation and had higher confidence in BSE were more likely to perform the screening (Akhtari-Zavare1, Hanafiah-Juni, Said, \& Zarina, 2013). Another study also found that higher scores of perceived benefits, perceived confidence/self-efficacy, and health motivation showed significant positive association with performing BSE in Iranian female students (Didarloo, Nabilou, \& Reza-Khalkhali, 2017). In Saudi women significant predictors of BSE performance were perceived barriers and perceived confidence (Abolfotouh, BaniMustafa, Mahfou, Al-Assiri1, Al-Juhani, \& Alaskar, 2015). These factors, along with perceived benefits and health motivation, are related to the regular practice of BSE (Erbil \& Bölükbaş, 2012).

There are only two studies of women's health-based cognitive beliefs in Mexico: one for BSE and one for MMG. Both demonstrated that self-efficacy influences decisions to practice BSE and MMG, but perceptions of susceptibility, the seriousness of possible consequences, and benefits differed (Cancino, 2004; Ponce, 2013). These studies were conducted in women over 40 years old, and did not use a health belief scale previously validated and adapted to our culture, which resulted in obstacles to reliably identifying which factors influence breast cancer detection behavior.

Therefore, the objective of this study is to identify knowledge about BSE, its practice, socio-demographic factors, and the dimensions of HBM (susceptibility, seriousness, benefits, barriers, perceived self-efficacy, and health motivation), which can predict BSE practice and could help us to design strategies for adequate promotion of BSE. 


\section{Method}

A descriptive cross-sectional design was used with non-probabilistic sampling.

\section{Participants}

Of a total of 949 college students, the inclusion criteria were being a female college student and willingness to participate in the research. The exclusion criteria were a history or current diagnosis of cancer, pregnancy, and/or breast-feeding. Six college students did not answer all items of the Health Belief Model Scale for Breast Self-Examination. Therefore, only the data from 943 participants were analyzed.

Table 1

Characteristics of the Respondents

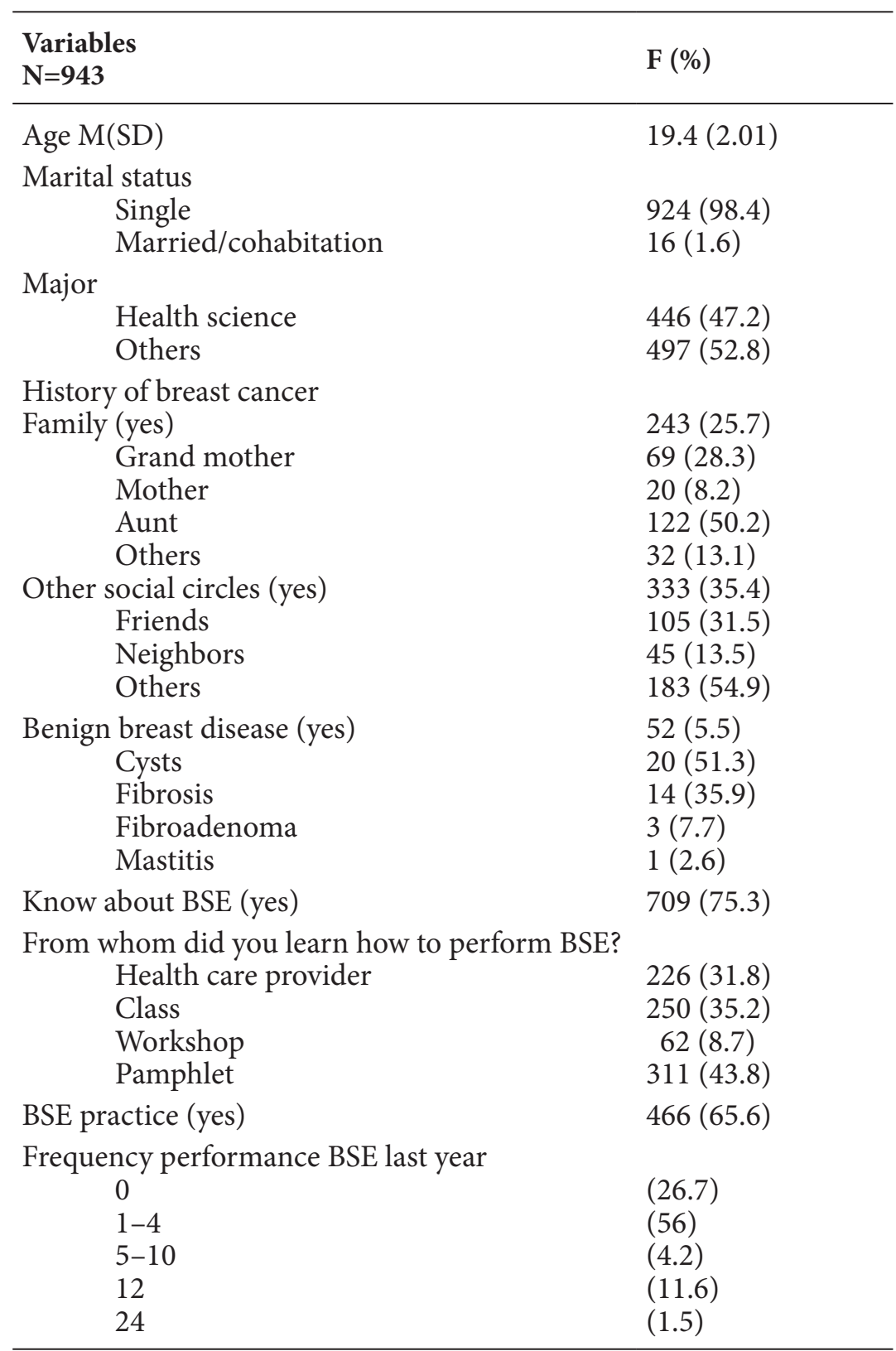


The age range was from 17 to 44 years; $94.7 \%$ were single; $47.2 \%$ were students in the health field; $5.5 \%$ reported a history of breast benign disease; $25.7 \%$ mentioned a family history of breast cancer; and $31.5 \%$ had encountered the disease in other social circles. When questioned about knowledge and practice of BSE, 75.3\% said they knew how to conduct the examination, $65.9 \%$ had performed it at least once, and $11.6 \%$ had performed it once a month in the previous year (Table 1).

\section{Measurements}

A general data questionnaire was administered, which consisted of general information questions, including age, marital status, breast cancer history in the family or close social circles, other breast diseases, knowledge of BSE, and frequency of BSE performance.

An additional Health Belief Model Scale for Breast Self-Examination questionnaire was administered (Champion, 1984). The Spanish adaptation by Juárez, Téllez, and García (2019) was used. It consists of 33 items that assess the six dimensions of the HBM for breast cancer and BSE: susceptibility ( $a .69)$, seriousness ( $\alpha .73)$, benefits ( $\alpha .72$ ), and barriers perceived ( $\alpha .77)$, as well as health motivation $(\alpha .80)$ and self-efficacy (a.87). The optional answers are presented in a 5-point Likert type scale ( $1=$ I totally agree, to $5=I$ totally disagree $)$.

\section{Procedure}

The data were collected in public schools from August 2016 to May 2017. Participation in this study was voluntary. The women had the study's objectives explained to them, and those who agreed to participate provided informed consent and responded to the questions. The data were collected in their schools' common areas, such as classrooms, cafeterias, and rest areas.

\section{Statistical Analysis}

SPSS software version 24 was used to conduct the statistical analysis. Descriptive data were obtained, including frequency, percentage, mean, and standard deviation of the variables. A Pearson correlation analysis was made between the practice frequency of BSE over the previous year and the dimensions of the HBM. To assess the differences in BSE practice, socio-demographic variables, and the dimensions of the health belief scale among the students, the chi-squared and the Student's t-tests were used. To perform the logistic regression analysis, based on a review of the literature, a wide array of potential factors associated with BSE practice, such as a high level of BSE knowledge (Didarloo et al., 2017), family history of breast cancer (Abolfotouh et al., 2015), and study for a health-related profession (Gençtürk, Demirezen, \& Ay, 2017), was taken into account.

\section{Results}

\section{Correlation between the Practice Frequency of BSE in the Previous Year and the HBM Dimensions}

The results show that there is a negative and significant relationship between the frequency of BSE and perceived barriers $(\mathrm{r}=-.214, \mathrm{p}=.001)$, and a positive and 
significant relationship between the frequency of BSE and perceived self-efficacy $(\mathrm{r}=.358, \mathrm{p}=.001)$.

\section{Comparison Analysis between the College Students who Perform BSE and Those Who Do Not}

The groups that do, or do not, perform the BSE were formed by their answers to the question: Since you learned to perform BSE, have you done a breast self-exam? When performing the comparison analysis, significant differences between the college students who performed BSE and those who did not were observed in age, benign breast disease, family breast cancer history, and benefits and barriers perceived, as well as in the self-efficacy and health motivation (Table 2).

Table 2

Comparison between Those Performing and Those Who Did Not BSE

\begin{tabular}{lccc}
\hline \multicolumn{1}{c}{$\begin{array}{c}\text { Variable } \\
\mathbf{N}=\mathbf{7 0 8}\end{array}$} & $\begin{array}{c}\text { Performance BSE } \\
\mathbf{f}(\mathbf{\%}) \\
\mathbf{n = 4 6 5}\end{array}$ & $\begin{array}{c}\text { No Performance } \\
\mathbf{B S E} \\
\mathbf{n = 2 4 3}\end{array}$ & $\mathbf{X}^{2} / \mathbf{g l} \mathbf{( \mathbf { p } )}$ \\
\hline $\begin{array}{l}\text { Major } \\
\quad \text { Health sciences }\end{array}$ & $262(61.8)$ & $103(28.2)$ & \\
$\quad$ Others & $204(59.1)$ & $141(40.9)$ & $12.5[1](.000)$ \\
Benign breast disease & $35(7.5)$ & $8(3.3)$ & $5.04[1](.025)$ \\
History of breast cancer & & & \\
$\quad$ Family & $126(27)$ & $48(19.7)$ & $4.69[1](.030)$ \\
$\quad$ Friends & $176(38)$ & $84(34.6)$ & $.813[1](.367)$ \\
Know about BSE & $464(65.9)$ & $240(34.1)$ & $2.79[1](.094)$ \\
& $\mathbf{M}(\mathbf{S D})$ & & $\mathbf{t}[\mathbf{g l}](\mathbf{p})$ \\
Age & $19.7(1.9)$ & $19.3(2.4)$ & $2.61[708](.009)$ \\
Susceptibility & $10.6(2.9)$ & $10.6(2.7)$ & $.198[706](.843)$ \\
Seriousness & $14.6(3.8)$ & $15.2(3.8)$ & $-1.79[699](.073)$ \\
Benefits & $15.7(3.0)$ & $15.2(3.0)$ & $2.02[707](.043)$ \\
Barriers & $10.2(3.4)$ & $12.4(3.9)$ & $-7.66[707](.000)$ \\
Self-efficacy & $34.3(5.7)$ & $30.2(5.4)$ & $9.22[704](.000)$ \\
Health motivation & $20.9(2.8)$ & $20.0(3.5)$ & $3.43[411](.001)$ \\
\hline
\end{tabular}

A stepwise logistic regression analysis was performed (Table 3). The independent variables comprised the general characteristics and dimensions of HBM that showed significant differences in the t-test and $\chi$-squared test. Step 4 shows the model with the best fit based on -2LL (772.8), and on the omnibus test that was significant $\left(\chi^{2}[4]=114.9, p=.001\right)$; the factors predicting BSE practice were the barriers perceived, self-efficacy, suffering a benign breast disease, and college major. 
Table 3

Logistic Regression Analysis for Performing BSE

\begin{tabular}{lccccccc}
\hline \multicolumn{1}{c}{ Variable } & B & SE & Wald & P value & OR & \multicolumn{2}{c}{$95 \%$ CI } \\
\hline $\begin{array}{l}\text { Step 1 } \\
\text { Self-efficacy }\end{array}$ & .135 & .016 & 68.8 & .000 & 1.145 & 1.109 & 1.182 \\
Constant & & & & & & & \\
$\mathrm{R}^{2}$ Nagekerke $=0.15$ & -3.70 & .523 & 50.3 & .000 & .025 & & \\
Step 2 & & & & & & & \\
Barriers & -.115 & .024 & 22.4 & .000 & .891 & .850 & .935 \\
Self-efficacy & .114 & .017 & 45.0 & .000 & 1.121 & 1.084 & 1.158 \\
Constant & & & & & & & \\
$\mathrm{R}^{2}$ Nagekerke =0.19 & -1.71 & .662 & 6.71 & .010 & .180 & & \\
Benign breast disease & .826 & .427 & 3.73 & .053 & 2.284 & .988 & 5.277 \\
Step 3 & & & & & & & \\
Barriers & -.118 & .025 & 23.1 & .000 & .889 & .847 & .932 \\
Self-efficacy & .112 & .017 & 43.7 & .000 & 1.119 & 1.082 & 1.157 \\
Constant & & & & & & & \\
$\mathrm{R}^{2}$ Nagekerke =0.20 & -1.67 & .664 & 6.38 & .012 & .187 & & \\
Step 4 & .383 & .177 & 4.66 & .031 & 1.466 & 1.036 & 2.075 \\
Major & .909 & .430 & 4.46 & .035 & 2.481 & 1.068 & 5.761 \\
Benign breast disease & -.115 & .025 & 21.7 & .892 & .850 & .178 & .936 \\
Barriers & .108 & .017 & 39.5 & .000 & 1.114 & 1.177 & 1.153 \\
Self-efficacy & & & & & & & \\
Constant & -1.77 & 671 & 6.98 & .008 & .170 & & \\
$\mathrm{R}^{2}$ Nagekerke =0.21 & & & & & & & \\
\hline
\end{tabular}

Significance ${ }^{*} p<.001,{ }^{*} p<.05, B$ : Coefficient B, OR: Odds Ratio, SE: Standard error, CI: Confidence Interval.

\section{Discussion}

BSE enables women to know their body and notice any changes during their monthly examinations. In many cases, this helps them to detect tumors. Therefore, it is important to teach them this technique (Torres-Mejía et al., 2011).

Breast cancer rates and mortality have increased in young women. Therefore, it is important to identify their beliefs about breast cancer and BSE (Villarreal-Garza et al., 2013). This study found that $75.3 \%$ knew how to perform BSE, and $65.9 \%$ had done so. These percentages are lower than those reported in women over 20 years of age in the general population from Mexico, which found that $82.8 \%$ know about BSE, and $73.7 \%$ perform it on a periodic basis (Yépez-Ramírez, De la Rosa, Guerrero-Albarrán, \& Gómez-Martínez, 2012).

Our results are similar to other Latin American studies. For example, 91\% of Peruvian medical students reported knowledge of the BSE, but only $71 \%$ performed it regularly. The main reasons for not performing it were that they did not 
know how to do it; others felt that it was not necessary to perform it in the absence of symptoms, and some feared they might find something wrong (Gutiérrez-Delgadillo, Gutiérrez-Flores, Gutiérrez-Choque, Guzmán-Delgadillo, \& SantanderLópez, 2012). A study of college students from Colombia found that $85.9 \% \mathrm{knew}$ how to perform the BSE, and $77.8 \%$ had performed it; the majority agreed that it provided health benefits. Barriers to performing BSE included forgetting to do it, and the failure of health care providers to explain it fully (Carrillo-Díaz et al., 2015). Similarly, $80.9 \%$ of Ecuadorian college students are aware of the purpose of BSE, and 33.9\% perform it; the majority of the students showed a favorable attitude to performing BSE, considering it to be beneficial (Bermeo \& Chin-Uzhca, 2017).

The results obtained in this study about the beliefs and barriers to performing BSE are similar to those reported in the general population in Mexico, which indicate that the motivational factors in favor of performing BSE include cancer prevention, medical instructions, and a family history of breast cancer. The main reasons for not performing the BSE include not knowing how to perform it, a lack of time, apathy, and laziness (León, 2011; Yépez-Ramírez et al., 2012). In this study, students also believed that BSE could help them find a mass at an early stage, reduce their possibility of dying, and avoid radical treatment for breast cancer.

Students who did not perform BSE perceived more barriers to doing so, a perception which is also a significant predictor of BSE practice. From the HBM standpoint, barriers are understood as the physiological and psychological costs entailed in performing BSE, - that is, the negative aspects of BSE (Champion, 1984). The barrier that was the most prevalent, was the fear of finding something wrong. We suggest that health education strategies focus on identifying methods to eliminate this and other barriers among college students.

Studies conducted in Asian countries investigating BSE knowledge and practice also analyzed the most influential variables on BSE behavior. In female college students in Malaysia, 36.7\% indicated that they had performed BSE. In addition, students with more BSE knowledge, who were more focused on their health, and had a better perception of their self-efficacy, were more likely to perform the BSE (Akhtari-Zavare, Juni, Said, \& Ismail, 2013).

In Saudi Arabia, an extremely conservative country characterized by significant gender-based discrimination against women, only $22 \%$ of women aged between 15 and 29 years had practiced BSE; their practice was associated with their educational level and cancer awareness (Ravichandran, Al-Hamdan, \& Mohamed, 2011). Likewise, $27 \%$ of Korean college students practiced BSE, and the predicting variables involved were age, subject major, and BSE knowledge (Shin, Park, \& Kim, 2012). These data demonstrated that the percentage of students with BSE knowledge and practice was lower than in our study. However, among the variables that predict performing BSE, some matched those found in this study, mainly self-efficacy and their major area of study.

In European countries like Cyprus, $91.5 \%$ of young women have heard about BSE, and $71.3 \%$ have performed it, a higher percentage than in our study. Variables that influenced BSE practice included perceived susceptibility; an association was also found between BSE practice, perceived barriers, and self-efficacy, as well as BSE awareness and a high education level (Petro-Nustas, Tsangari, Phellas, \& Constantinou, 2013). This is similar to our study, where the barriers perceived, 
self-efficacy, history of benign breast disease, and studying health sciences had the highest influence on BSE practice.

Self-efficacy refers to the confidence a person has to perform an action (Champion \& Skinner, 2008). Our study found that the women who practice BSE experience greater self-efficacy than those who do not. When self-efficacy was analyzed in college students in general, women reported greater self-efficacy than men (Aguirre, Blanco, Rodríguez-Villalobos, \& Ornelas, 2015).

In contrast, a study of women over 20 years of age from the northern area of Mexico shows that the susceptibility dimension of HBM influences BSE practice (Cancino, 2004). This finding may differ because of age, the population studied, and low perceived susceptibility levels in this sample.

A history of benign breast disease also influences BSE performance. It can act as a trigger, and is consider a cue for action within the health beliefs model, and a stimulus that drives a person to take up a given behavior. Examples include remaining aware of and remembering breast cancer campaigns and the BSE, the influence of health care professionals and intimate others, as well as personal experiences with the disease (Cabrera, Tascón, \& Lucumí, 2001).

In this case, the experience of benign breast diseases causes women to be more attentive to their body and perform BSE more frequently. Similarly, students who perform BSE have had more family members, friends, and acquaintances with breast cancer, which can also act as a trigger to take action.

The variables with the greatest predictive value of BSE practice among college students were self-efficacy and perceived barriers, both of which can be modified. Accordingly, health promotion strategies should focus their efforts on eliminating the barriers perceived, and on promoting BSE efficacy among students. Current efforts are directed mainly to eliminating breast cancer myths, rather than removing barriers to practicing BSE. There is a study that reports college students' myths about BSE (Tapia-Curiel et al., 2014). Another barrier is the fear of finding something wrong; therefore, an intervention is also required in this area.

Self-efficacy involves the capacity to confidently deploy the necessary skills to perform a specific task (Bandura, 1997). Information about self-efficacy can be obtained from a woman's achievements, life experience, verbal persuasiveness, and physiological status. Performance achievements are considered the most influential information sources because they are based on personal experience (Rosenstock, Strecher, \& Becker, 1988). Thus, an intervention is required to improve perceived self-efficacy in addition to providing knowledge about BSE, to order to ensure that women practice it to increase their skills. Psycho-educational interventions have had positive effects on promoting BSE in all the dimensions of the HBM scale (Yılmaz, Sayın, \& Öner-Cengiz, 2017).

\section{Conclusion}

Reports of BSE practice in female students from Latin American countries are similar; however, the predictive variables differ from those found in the general population. Studying in a health-related area, having a history of benign breast disease, and breast cancer in the family are associated with the practice of BSE; the dimensions of the health belief model that relate to, and predict, the practice of BSE 
are the perceived barriers and perceived self-efficacy, which are factors that can be modified through intervention. Therefore it is recommended that these variables be taken into account when designing intervention strategies to improve the practice of BSE in female students.

\section{Limitations}

It is important to consider the limitations of this study. The first is that the results cannot be generalized to women of all ages and educational levels, because this study was conducted with young women with a higher education. Second, this study assessed their beliefs about BSE practice based on self-reports. Therefore, the results could be affected by the social desirability of BSE practice. However, this study provides us with information about college students' perceptions of BSE. College students who performed BSE were more likely to have had family members and friends with breast cancer, have suffered a benign breast disease, or be studying a health sciences major. They found it beneficial, felt more self-efficacious, and were more interested in their health in general. They also perceived fewer barriers to performing BSE than those who do not practice it.

\section{Acknowledgements}

This work was supported by the Crusade AVON against breast cancer.

\section{References}

Abraham, C., \& Sheeran, P. (2015). The Health Belief Model. In M. Cornen and P Norman (Eds.), Predicting and Changing Health Behavior: Research and Practice with Social Cognition Models. 3rd ed. 30-69. Maidenhead, UK: Open University Press.

Abolfotouh, M.A., Ala’a, A.B., Mahfouz, A.A., Al-Assiri, M.H., Al-Juhani, A.F., \& Alaskar, A. S. (2015). Using the health belief model to predict breast self examination among Saudi women. BMC Public Health, 15(1), 1163-175. https://doi.org/10.1186/s12889-015-2510-y

Agudelo-Botero, M. (2013). Sociodemographic Determinants of Access to Breast Cancer Screening in Mexico: A Review of National Surveys. Salud Colectiva, 9(1), 79-90. https://doi.org/10.1590/S1851-82652013000100007

Aguirre, J.F., Blanco, J.R., Rodríguez-Villalobos, J.M., \& Ornelas, M. (2015). Autoeficacia General Percibida en Universitarios Mexicanos, Diferencias entre Hombres y Mujeres [General Perceived Self-Efficacy in Mexican University Students, Differences between Men and Women]. Formación universitaria, 8(5), 97-102. https://doi.org/10.4067/S0718-50062015000500011

Ahmadian, M., \& Samah, A.A. (2013). Application of Health Behavior Theories to Breast Cancer Screening among Asian Women. Asian Pacific Journal of Cancer Prevention: APJCP, 14(7), 40054013. https://doi.org/10.7314/APJCP.2013.14.7.4005

Akhtari-Zavare, M., Juni, M.H., Said, S.M., \& Ismail, I.Z. (2013). Beliefs and Behavior of Malaysia Undergraduate Female Students in a Public University Toward Breast Self-Examination Practice. Asian Pacific Journal of Cancer Prevention: APJCP, 14(1), 57-61. https://doi.org/10.7314/APJCP.2013.14.1.57

Bandura, A. (1997). Self-Efficacy: The Exercise of Control. New York: W.H. Freeman.

Bermeo, C. \& Chin-Uzhca, G. (2017). Conocimientos, actitudes y prácticas sobre autoexamen de mamas en estudiantes de Odontología de la Universidad de Cuenca, 2016 [Knowledge, attitudes and 
practices on breast self-examination in Dentistry students of the University of Cuenca, 2016]. (Bachelor's Thesis). Retrieved from http://dspace.ucuenca.edu.ec/handle/123456789/26466

Cabrera, A.G., Tascón, G.J., \& Lucumí, C.D. (2001). Creencias en Salud: Historia, Constructos y aportes del Modelo [Beliefs in Health: History, Constructs and Contributions to the Model]. Revista Facultad Nacional de Salud Pública, 19(1), 91-101.

Cancino, M. (2004). Práctica de autoexploración de mamas, susceptibilidad y

Autoeficacia percibida [Breast self-exploration practice, susceptibility and perceived self-efficacy]. (Bachelor's Thesis). Retrieved from http://eprints.uanl.mx/1357/1/1080084852.PDF

Carrillo-Diaz, E., Castro-Rodriguez, D., Hernandez-Bello, L., Osorio-Trucco, M.T., RhenalsPerez, L., \& Villadiego-Orozco, A. (2015). Conocimientos, actitudes y prácticas sobre el autoexamen de mama en estudiantes universitarias del área de la salud de Cartagena 2015 [Knowledge, attitudes and practices on breast self-examination in university students of the health area of Cartagena 2015]. (Bachelor's Thesis). Retrieved from http://repositorio.unicartagena.edu. co:8080/jspui/bitstream/11227/4512/1/Informe\%20final\%20CAP\%20mama.pdf

Champion, V.L. (1984). Instrument Development for Health Belief Model Constructs. Advances in Nursing Science (ANS), 6(3), 73-85. https://doi.org/10.1097/00012272-198404000-00011

Champion, V., \& Skinner, C. (2008). The Health Belief Model. In Glanz, K. Rimer, B.K. \& Viswanath, K. (Eds.), Health Behavior and Health Education: Theory, Research, and Practice (pp. 45-65). San Francisco CA: John Wiley \& Sons.

De la Vara-Salazar, E., Suárez-López, L., Ángeles-Llerenas, A., Torres-Mejía, G., \& Lazcano-Ponce, E. (2011). Tendencias de la mortalidad por cáncer de mama en México, 1980-2009 [Breast Cancer Mortality Trends in Mexico, 1980-2009]. Salud Pública de México, 53(5), 385-393.

Didarloo, A., Nabilou, B., \& Khalkhali, H.R. (2017). Psychosocial predictors of breast self-examination behavior among female students: an application of the health belief model using logistic regression. BMC Public Health, 17(1), 861-869. https://doi.org/10.1186/s12889-017-4880-9

Erbil, N., \& Bölükbaş, N. (2012). Beliefs, attitudes, and behavior of Turkish women about breast cancer and breast self-examination according to a Turkish version of the Champion Health Belief Model Scale. Asian Pac. J. Cancer Prev. 13(11), 5823-8. https://doi.org/10.7314/APJCP.2012.13.11.5823

Frenk, J. (2009). Sensibilización, detección temprana y combate a los prejuicios. Claves en la lucha contra el cáncer de mama [Building Awareness, Promoting Early Detection and Combating Prejudices. Keys in the Fight against Breast Cancer]. Salud Pública de México, 51(2), 135-137. https://doi.org/10.1590/S0036-36342009000800001

Gençtürk, N., Demirezen, E., \& Ay, F. (2017). Health Beliefs of Midwifery Students at Istanbul University about Breast Cancer and Breast Self-Examination Acknowledgements. Journal of Cancer Education, 32(4), 784-789. https://doi.org/10.1007/s13187-016-1014-5

Gutiérrez-Delgadillo, A., Gutiérrez-Flores, F.R., Gutiérrez-Choque, J.C., Guzmán-Delgadillo F., \& Santander-López, A. (2012). Conocimiento, actitud y práctica del autoexamen mamario en mujeres estudiantes de medicina de la Universidad Mayor de San Simón Gestión 2011 [Knowledge, Attitude and Practice of Breast Self-Examination in Female Medical Students of the Universidad Mayor de San Simón 2011]. Revista Cientíica Ciencia Médica, 15(2), 22-25.

Hajian-Tilaki, K., \& Auladi, S. (2014). Health belief model and practice of breast self-examination and breast cancer screening in Iranian women. Breast Cancer, 21(4), 429-434. https://doi.org/10.1007/s12282-012-0409-3

Juárez- García, D. M., Téllez, A., \& García-Cadena, C. (2019). Escala del modelo de creencias de salud para la autoexploración de mama en estudiantes universitarias [The health beliefs model scale for breast self-examination in university students]. Acta de Investigación Psicológica, 9(1), 7-14.

León, D. (2011). Factores asociados al diagnóstico no oportuno de cáncer de mama. [Factors associated with the untimely diagnosis of breast cancer]. (Bachelor's Thesis). Universidad Veracruzana. México. 
Martínez-Cruz, G., Juárez-Ramiro, A., Pichardo-Cuevas, M., \& Martín- Ordoñez, J. (2010). Cáncer de mama en mujeres menores de 40 años. Una evolución desfavorable cada vez más frecuente en la práctica clínica [Breast Cancer in Women under 40 Years. Unfavorable Outcome Increasingly in Clinical Practice]. GAMO, 9(6), 242-245.

National Institute of Statistics and Geography. Statistics about the ... World cancer day (February 4) National data (2017). Mexico National Institute of Statistics \& Geography Web Site. Retrieved from http://www.inegi.org.mx/saladeprensa/aproposito/2017/cancer2017_Nal.pdf

National Institute of Statistics and Geography. Statistics about the ... World cancer day (February 4) national data (2018). Mexico National Institute of Statistics \& Geography Web Site. Retrieved from http://www.beta.inegi.org.mx/contenidos/saladeprensa/aproposito/2018/cancer2018_Nal.pdf

Nigenda, G., Caballero, M., \& González-Robledo, L. (2009). Barreras de acceso al diagnóstico temprano del cáncer de mama en el Distrito Federal y en Oaxaca [Access Barriers in Early Diagnosis of Breast Cancer in the Federal District and Oaxaca.] Salud Pública de México, 51(2), 254-262. https://doi.org/10.1590/S0036-36342009000800016

Petro-Nustas, W., Tsangari H., Phellas, C., \& Constantinou, C. (2013). Health Beliefs and Practice of Breast Self-Examination among Young Cypriot Women. Journal of Transcultural Nursing: Official Journal of the Transcultural Nursing Society, 24(2), 180-188. https://doi. org/10.1177/1043659612472201

Ponce, M.R. (2013). Creencias en salud asociadas a la realización de la mastografía para la detección oportuna de cáncer de mama en mujeres de 50-69 años de edad en la UMF 8 del IMSS en Aguascalientes [Health beliefs associated with mammography for the timely detection of breast cancer in women 50-69 years of age in the UMF8 of the IMSS Aguascalientes]. (Bachelor's Thesis). Retrieved from http://bdigital.dgse.uaa.mx:8080/xmlui/handle/11317/1103

Ravichandran, K., Al-Hamdan, N. A., \& Mohamed, G. (2011). Knowledge, Attitude, and Behavior among Saudis Toward Cancer Preventive Practice. Journal of Family \& Community Medicine, 18(3), 135-142. https://doi.org/10.4103/2230-8229.90013

Robles-Castillo, J., Ruvalcaba-Limón, E., Maffuz-Aziz, A., \& Rodríguez-Cuevas, S. (2011). Cáncer de mama en mujeres mexicanas menores de 40 años [Breast Cancer in Mexican Women under 40]. Ginecología y Obstetricia de México, 79(8), 482-488.

Rosenstock, I.M., Strecher, V.J., \&. Becker, M.H. (1988). Social Learning Theory and the Health Belief Model. Health Education Quarterly, 15(2), 175-183. https://doi. org/10.1177/109019818801500203

Shin, K.R., Park, H.J., \& Kim, M. (2012). Practice of Breast Self-Examination and Knowledge of Breast Cancer among Female University Students in Korea. Nursing \& Health Sciences, 14(3), 292-297. https://doi.org/10.1111/j.1442-2018.2012.00696.x

Tapia-Curiel, A., Nuño-Gutiérrez, B.L., Flores-Padilla, L., Villaseñor-Farías, M., \& López-López, J.L. (2015). Campañas de Percepciones de Adolescentes Jalisco sobre Cáncer de Mama [Perceptions of Adolescents Jalisco Campaign on Breast Cáncer]. Revista Médica del Instituto Mexicano del Seguro Social, 53(4), 414-421.

Tapia-Curiel, A., Villaseñor-Farías, M., Nuño-Gutiérrez, B., Rodríguez-Carlos A., Salas-González, E., \& López-López, J.L. (2014). Representación social que los adolescentes de Jalisco, México, tienen de la detección precoz del cáncer de mama [The Social Representation That Adolescents from Jalisco, Mexico Have of Early Detection of Breast Cancer]. Atención Primaria, 46(8), 408-415. https://doi.org/10.1016/j.aprim.2013.12.006

Tenahua-Quitl, I., Arrioja-Morales, G., Salazar-Peña, M.T.L., Sifuentes-Pasillas, P.G., Antonio-López, M.T., \& De León-Gómez, A. (2017). Conocimiento, razones y mitos en estudiantes de enfermería sobre la autoexploración de mama [Knowledge, Reasons and Myths in Nursing Students about Breast Self-Exploration]. Revista de Enfermeria del Instituto Mexicano del Seguro Social, 25(2), 95-99. 
Torres-Mejía, G., Knaul, F. M., Ortega-Olvera, C., Magaña-Valladares, L., Uscanga-Sánchez, S.R., \& Lazcano-Ponce, E. (2011). Detección temprana y manejo integral del cáncer de mama [Early Detection and Comprehensive Management of Breast Cancer]. Manual Directed for Medical and Nursing Staff of the First Level of Care. National Public Health Institute. Cuernavaca, México.

Villarreal-Garza, C., Aguila, C., Magallanes-Hoyos, M.C., Mohar, A., Bargalló, E., Meneses, A... \& Barrio, C. (2013). Breast Cancer in Young Women in Latin America: an Unmet, Growing Burden. The Oncologist, 18, 26-34. https://doi.org/10.1634/theoncologist.18-S2-26

Yépez-Ramírez, D., De La Rosa, A.G., Guerrero-Albarrán, C., \& Gómez-Martínez, J.M. (2012). Autoexploración mamaria: conocimiento y perspectiva en mujeres [Breast Self-Exploration: Knowledge and Perspective in Women]. Revista de Enfermería del Instituto Mexicano del Seguro Social, 20(2), 79-84.

Yılmaz, M., Sayın, Y., \& Öner-Cengiz, H.Ö. (2017). The Effects of Training on Knowledge and Beliefs about Breast Cancer and Early Diagnosis Methods among of Women. European Journal of Breast Health, 13, 175-182. https://doi.org/10.5152/tjbh.2017.3255

Original manuscript received January 11, 2019

Revised manuscript accepted August 04, 2019

First published online September 30, 2019

To cite this article: Juárez-García, D.M., Téllez, A. (2019). The Health Belief Model and Prediction of Breast Self-examination Practices in Female Mexican College Students. Psychology in Russia: State of the Art, 12(3), 73-85. DOI: 10.11621/pir.2019.0306 